\title{
Analysis of Integrated ANC Services on the Satisfaction and Event of High Risk in Pregnantmother in Islamic Hospital Bangil Pasuruan
}

\author{
Ety Diana Sulistyawati ${ }^{1}$, \\ Byba Melda Suhita ${ }^{2}$, Nurdina ${ }^{2}$ \\ ${ }^{1}$ Magister of Health Study Program \\ of Institut Ilmu Kesehatan \\ STRADA Indonesia \\ ${ }^{2}$ Lecturer of Institut Ilmu \\ Kesehatan STRADA Indonesia \\ Email: \\ stikessuryamitrahusada@gmail.com
}

Received : October 12, 2019

Accepted : February 13, 2020

Published : May 11, 2020

\begin{abstract}
Maternal Mortality can be prevented by early detection of high risks or complications during pregnancy, by conducting prenatal checks into available health services. The high maternal mortality rate indicates that the quality of maternal health services that are still low includes antenatal care (ANC) services. The purpose of the study was to analyze integrated anc services for satisfaction and high risk events of pregnant women at Masyithoh Bangil Pasuruan Islamic Hospital. The research design used is quantitative research with a cross sectional approach. Instrument data used questionnaire sheets using Chi Square test and Ordinal Regression. The results of the analysis of chi square test between variables ANC services integrated with satisfaction of pregnant women obtained p-value $0,000<0,05$, meaning that there is a relationship between integrated ANC services to satisfaction of pregnant women at Masyithoh Bangil Pasuruan Islamic Hospital. Whereas between integrated ANC service variables with high risk events obtained p-value $0.015<0.05$, meaning that there is a relationship between integrated ANC services to the high risk incidence of pregnant women at Masyithoh Bangil Pasuruan Islamic Hospital. Based on the results of the Ordinal Regression Test analysis shows that the most influential variable with the Integrated ANC Service at the Masyithoh Bangil Pasuruan Islamic Hospital is the variable satisfaction of pregnant women with a p-value of $0,000<0,05$. It is expected that respondents can conduct an Integrated ANC on a regular basis and the service can remain satisfactory.
\end{abstract}

Keywords: Integrated ANC, high risk events of pregnant women, satisfaction 


\section{INTRODUCTION}

An antenatal care service is a basic health service for pregnant women that must be carried out according to the standard, which is at least 4 times during pregnancy. Every pregnancy can develop into a problem or complication, so monitoring is needed during pregnancy. Pregnant women also need to know about the dangers of pregnancy. If pregnant women know about the dangers of pregnancy, then pregnant women will be more alert and careful by doing routine checks during the pregnancy. The worst possible complication of pregnancy can cause death in pregnant women (Suwargono, 2015).

Maternal Mortality Rate should be prevented by early detection of high risk or complications during pregnancy, by making visits or prenatal check-ups to available health services. The high maternal mortality rate indicates that the quality of maternal health services is still low, including antenatal care (ANC) services for pregnant women (Suwargono, 2015).

If the quality of antenatal care services is not good, it will affect the initial visit of pregnant women (K-1) and the second visit in the third trimester (K-4) which will affect the maternal mortality rate and infant mortality rate. This is evident from the data obtained from the Pasuruan District Health Office in 2013 the percentage of initial visits of pregnant women (K-1) $99 \%$ and the second visit in the third trimester (K-4) 90\% still did not meet the 2015 national target, namely the target for (K-1) 100\% and the target for (K-4) is $100 \%$. The Maternal Mortality Rate (MMR) still exists, namely 157.39 / 100,000 live births and the Infant Mortality Rate (IMR) still exists, namely 10.59 / 1000 live births. Childbirth by health workers (health worker delivery) $91 \%$ also still does not meet the target of $95 \%$ (Pasuruan Health Office, 2014). The results of the research conducted by Kamisah (2002) indicate a significant relationship between the quality of antenatal care and patient satisfaction.

Based on reports that the maternal mortality rate (AKI / MMR) in the last 10 years in Indonesia fluctuated, namely from 307 per 100,000 live births in 2002 or $0.08 \%$ down to 228 per 100,000 live births in 2007 or $0.26 \%$ then rose drastically to 359 per 100,000 people live births or $0.57 \%$ in 2012 . Have AKI targets in the 2015 MDG'S (WHO 2016)

Various national MCH policies that have been issued by the government are like the Making Pregnancy Safer (MPS) strategy in response to the WHO which launched Safe Motherhood Initative in 1987. For three decades, namely in 1980 - 2010 Indonesia was a country that succeeded in managing the MCH program, but what happened was the opposite happened AKI fluctuations which meant a decline in achieving the AKI target from year to year. Several other programs are related to supporting efforts to improve MCH, namely DTPS - KIBBLA (District Team Problem Solving for Maternal Health). The program has six KIBLA DTPS approach programs, namely Kangaroo Method Care (PMK), Standby Village, SBMR (Standard Based Management Recognition). And AMP (Perinatal Matrenal Care). Maternity Planning and Complication Prevention (P4K) Program. Darling Mother Movement (GSI), Childbirth Assurance (Jampersal) and Health Operational Assistance (BOK). It turns out that it has not been able to reduce AKI (WHO, 2015).

Based on a preliminary study conducted on 3 informant mothers of pregnant women on November 10, 2018 at the RSI Gynecology Department, Masyithoh Bangil, in getting the results that the Integrated ANC service was very well implemented in this hospital, the hospital had used the best equipment here and the service at the hospital has also been very good, this was stated by the three informants. But for some things the informants said were not good, this was due to the lack of information outside the hospital that he got about the risks of complications in pregnancy, which led to the community there might be some who did not know about the benefits of Integrated ANC and risks to the mother and fetus if not implementing the program. Information like this is only obtained when informants meet with health workers, and if they do not meet they will not get information like this.

ANC or antenatal care is the care of the mother and fetus during pregnancy. Through ancillary information and education related to pregnancy and childbirth preparation can be given to the mother as early as possible. Lack of knowledge about the danger signs of pregnancy often occurs because of the lack of these visits can cause harm to both the mother and the fetus such as the occurrence of bleeding during pregnancy because there are no signs of danger detected. (WHO, 2016).

WHO recommends several things related to ANC such as the importance of developing clinical policies and protocols related to maternal and child health. This guide complies with standard operating procedures (SOPs) which include; (i) identification of the priority issues and expected outcomes. (ii) 
Collecting evidence of reported problems, (iii) evaluating existing (iv) formulating recommendations and (v) planning for implementation, dissemination, and impact and evaluation (WHO 2016).

The Indonesian Ministry of Health has compiled the Integrated Antenatal Service Guidelines. This guidance is expected to become a reference for health workers in providing quality integrated Antenatal services to improve maternal health status which will ultimately contribute to a reduction in maternal mortality. The Integrated ANC Guidelines were prepared by the Directorate General of Community Health based on input from the expert Team and Evidence Based in the field which was then introduced in 2010 through the Directorate General of Community Health.

The arrangement of Antenatal Care service guidelines can be a benchmark for success in ANC, meaning that it can save lives or reduce MMR. Through ANC, the opportunity to deliver education and health promotion to pregnant women can be done better especially (WHO 2016). With this achievement, the satisfaction of pregnant women to health services in their care will increase and there will be no concern about the incidence of maternal and fetal deaths, while it can also reduce the likelihood of birth defects.

How to provide satisfactory service to patients has been set in the Integrated Antenatal Care service guide. The service is provided by doctors, midwives and trained nurses, while the type of examination of services is given to all pregnant women. Integrated ANC services are as many as 18 types of examination, namely general condition, body temperature, blood pressure, weight, LILA, TFU, fetal presentation, DJJ, HB, blood type, urine protein, blood sugar / reduction, malaria blood, AFB, syphilis blood, serology of HIV and USG. The subsequent implementation of integrated Antenatal Care services has been strengthened by the issuance of the health minister's policy contained in article 6 paragraph 1 letter B Permenkes No. 25 of 2014 concerning child health efforts, one of which is stated that fetal health services in the womb are carried out antenatal examinations for pregnant women and service to pregnant women is carried out periodically standard which is at least 4 times during pregnancy (K1 $\mathrm{K} 4)$.

\section{METHODS}

In this study, researchers used a quantitative analytical design with a cross sectional approach, namely a study to study the dynamics of correlation between risk factors and effects, by means of approach, observation or data collection at a time (point time approach), that is, each subject the study was only observed once and measurements were made on the character status or subject variable at the time of examination. This does not mean that all research subjects were observed at the same time (Soekidjo, 2002). This study will analyze integrated anc services to the satisfaction and high risk events of pregnant women at the Masyithoh Bangil Pasuruan Islamic Hospital

The number of samples of this study were 109 respondents with the sampling technique using simple random sampling. Data analysis using Ordinal Regression test.

\section{RESULTS}

The results of the chi square test between the ANC service variables integrated with the satisfaction of pregnant women obtained p-value $0,000<0,05$, $\mathrm{H} 0$ was rejected and $\mathrm{H} 1$ was accepted, meaning that there is a relationship between integrated ANC services to satisfaction of pregnant women at Masyithoh Bangil Pasuruan Islamic Hospital.

The results of the chi square test between integrated ANC service variables with high risk events were obtained p-value $0.015<0.05$, $\mathrm{H} 0$ was rejected and $\mathrm{H} 1$ was accepted, meaning that there was a relationship between integrated ANC services to the high risk incidence of pregnant women at Masyithoh Bangil Islamic Hospital Pasuruan. 
Table 1. Results of ordinal regression analysis Analysis of Integrated ANC Services Against Satisfaction And High Risk Events Of Pregnant Women At Masyithoh Bangil Islamic Hospital Pasuruan.

\begin{tabular}{|l|l|l|l|}
\hline No & Variabel & Estimate & Sig \\
\hline 1 & Constant & -23.522 & 0,000 \\
\hline 2 & Kepuasan & -23.391 & 0,000 \\
\hline 3 & Kejadian Resiko Tinggi & -21.570 & $\mathbf{0 , 1 1 3}$ \\
\hline
\end{tabular}

Based on Table 1 the results of the Ordinal Regression Test analysis show that the most influential variable with the Integrated ANC Service at Masyithoh Bangil Pasuruan Islamic Hospital is the variable satisfaction of pregnant women with a p-value of $0,000<0,05, \mathrm{H} 0$ is rejected and $\mathrm{H} 1$ is accepted so it is concluded that there is a significant relationship between integrated ANC services to satisfaction of pregnant women at Masyithoh Bangil Pasuruan Islamic Hospital.

\section{DISCUSSION}

Integrated ANC Services for Pregnant Women at Masyithoh Bangil Pasuruan Islamic Hospital

From the results of the research in getting almost all respondents as many as 77 respondents (70.6\%) had ANC services in a good category, in addition 21 respondents (19.3\%) had ANC services in sufficient categories and only 11 respondents $(10.1 \%)$ who have ANC services in less categories. At Masyithoh Bangil Pasuruan Islamic Hospital has a good Integrated ANC service, and this is felt by many patients. Where at the Hospital has implemented a method of examining pregnant women 14T according to the $\mathrm{MCH}$ book, ranging from height measurements to the provision of treatment by health workers there. With good service, patients will feel comfortable when carrying out Integrated ANC treatment at the Hospital.

\section{Satisfaction of Pregnant Women Doing Integrated ANC Services at Masyithoh Bangil Pasuruan Islamic Hospital}

From the results of the study it was found that almost all respondents had satisfaction in enough categories as many as 84 respondents $(77.1 \%)$, besides that, 19 respondents $(17.4 \%)$ had satisfaction in good categories and only as many as 6 respondents $(5.5 \%)$ have satisfaction in less categories.

Patient satisfaction is influenced by several factors, namely the appearance of a neat, clean and cool hospital in most of its sides, as well as the reliability or ability of each health worker in the hospital where each service is in accordance with the SOP (Standard Operational Procedure), also because of good staff responsiveness, health service guarantees if there is an error in carrying out the Integrated ANC and high empathy from each health worker who works at Masyithoh Bangil Pasuruan Islamic Hospital.

\section{High Risk Events of Pregnant Women in Masyithoh Bangil Pasuruan Islamic Hospital}

From the research, it was found that almost all respondents had a risk incidence of pregnant women in the high risk category of 86 respondents (78.9\%). In addition, 13 respondents (11.9\%) had a risk incidence of pregnant women in the low risk category and only 10 respondents $(9.2 \%)$ had a high risk incidence of pregnant women in the risk category.

The high risk incidence of pregnant women is influenced by the majority of mothers who have experienced pregnancy failure or miscarriage, besides that most of the mother's height is less than $145 \mathrm{~cm}$, besides that the mother gives birth and is caused a high-risk pregnancy and most mothers experience a pregnancy condition in which the fetus before performing the Integrated ANC experiences latitude. These high-risk pregnancies are influenced by the mother's ignorance regarding how to avoid high-risk pregnancies and how to get a good pregnancy with minimal risk.

\section{The Relationship of Integrated ANC Services to Satisfaction of Pregnant Women in Masyithoh Bangil Pasuruan Islamic Hospital}

From the results of ordinal regression statistical tests it is said that the satisfaction of pregnant women $p$ value $=0,000$ or $p$ value $<\alpha(0.05)$ and $\mathrm{H} 0$ is rejected, which means there is a relationship between integrated ANC services to satisfaction of pregnant women in Masyithoh Bangil Pasuruan 
Islamic Hospital, where most respondents with good ANC services getting satisfaction in enough categories as many as 63 respondents $(57.8 \%)$.

Good health care services will affect the satisfaction of Integrated ANC patients in these areas according to the results of the above research. Patient satisfaction is obtained because the service from the patient comes until the patient is approaching home impressed and pleases the patients who come.

\section{Relationship of Integrated ANC Services to High Risk Events of Pregnant Women at Masyithoh Bangil Pasuruan Islamic Hospital}

From the results of ordinal regression statistical tests it is said that the perception of the seriousness of $\mathrm{p}$ value $=0.113$ or $\mathrm{p}$ value $>\alpha(0.05)$ and $\mathrm{H} 0$ is accepted which means there is no relationship between integrated ANC services to the high risk incidence of pregnant women at Masyithoh Bangil Pasuruan Islamic Hospital, where some the number of respondents getting good ANC services had a high risk incidence in the high risk pregnancy category of 64 respondents $(58.7 \%)$.

Good service is expected to reduce the risk of a disease that is suffered by the patient. However, this is not in accordance with what is expected where the service is not related to the high risk of pregnancy. This is because the cause of the high risk of pregnant women is the old factor which starts from the height of the body, previous labor history, the condition of first pregnancy, etc. This condition cannot be changed only by good service, it is only possible to influence patients to routinely carry out pregnancy checks. Because the cause is far from being carried out by integrated ANC services, making it difficult for officers to associate services with high risk events in pregnant women.

\section{CONCLUSION}

At the Masyithoh Bangil Pasuruan Islamic Hospital has a good Integrated ANC service, and this is felt by many patients. Where at the Hospital has implemented a method of examining pregnant women 14T according to the KIA book

Good patient satisfaction, it is influenced by several factors, namely the appearance of a neat, clean and cool Hospital in most of its sides, in addition to the form because of the reliability or ability of each health officer in the Hospital where each service is performed in accordance with the SOP (Standard Operating Procedure).

The high risk of identified pregnant women is at high risk, where high-risk pregnancies are affected because of the mother's ignorance about how to avoid high-risk pregnancies and how to get a good pregnancy with minimal risk.

There is a relationship between integrated ANC services to the satisfaction of pregnant women at Masyithoh Bangil Pasuruan Islamic Hospital, where most respondents with good ANC services get satisfaction in sufficient categories.

There is no relationship between integrated ANC services for the high risk incidence of pregnant women at the Masyithoh Bangil Pasuruan Islamic Hospital, where most respondents get good ANC services having a high risk incidence in the high risk pregnancy category.

\section{SUGGESTION \\ For Respondents}

It is expected that respondents can conduct an Integrated ANC on a regular basis and the service can remain satisfactory.

\section{For Further Researchers}

It is expected that further researchers will need to be deepened and added more research on the effect of the period of pregnancy on the high risk of pregnancy in pregnant women.

\section{For Educational Institutions}

It is expected that educational institutions can use the results of this study as input of learning in the analysis of Integrated ANC services to satisfaction and high risk events of pregnant women and can be re-developed for further research to be more useful to readers and researchers. 


\section{BIBLIOGRAPHY}

Suwargono. 2015. Belajar dan Faktor-faktor yang Mempengaruhinya. Jakarta: PT. Rineka Cipta.

Dinkes. 2014. Profil Kesehatan Provonsi Jawa Timur. Pasuruan: Dinkes Jatim

Kamisah 2002. Sosiologi Kesehatan. Jakarta: Refika Aditama

WHO. 2016. Profile Kesehatan Indonesia. Retrieved Desember 10, 2018, from www.who.go.id/download/pusdatin

Kementrian Kesehatah RI. 2015. Buku Kader Seri kesehatan Anak. http://www.gizikia.depkes.go.id/download/Buku-Kader-Seri-Kesehatan Anak.pdf. Diakses tanggal 15 Desember 2017, pukul 14.00.

Soekidjo 2002. Riset Keperawatan dan Teknik Penulisan Ilmiah. Jakarta: Salemba Medika 